\title{
Determinants of Loan Defaults in Some Selected Credit Unions in Kumasi Metropolis of Ghana
}

\author{
Edward Yeboah1, Irene Mirekuah Oduro² \\ ${ }^{1}$ Department of Accounting and Finance, KNUST School of Business, Kwame Nkrumah University of Science and Technology \\ (KNUST), Kumasi, Ghana \\ ${ }^{2}$ St Peter's Cooperative Credit Union, Kumasi, Ghana \\ Email: eddie.yeboah401@gmail.com,imirekuahoduro@yahoo.com
}

How to cite this paper: Yeboah, E. and Oduro, I.M. (2018) Determinants of Loan Defaults in Some Selected Credit Unions in Kumasi Metropolis of Ghana. Open Journal of Business and Management, 6, 778-795. https://doi.org/10.4236/ojbm.2018.63059

Received: July 4, 2018

Accepted: July 28, 2018

Published: July 31, 2018

Copyright $\odot 2018$ by authors and Scientific Research Publishing Inc. This work is licensed under the Creative Commons Attribution International License (CC BY 4.0).

http://creativecommons.org/licenses/by/4.0/

\section{(c) (i) Open Access}

\begin{abstract}
Credit Unions play a pivotal role in the Microfinance Industry in Ghana. They are not only deeply rooted in financial intermediation but also provide favorable terms and conditions in financial products and services to their members compared to banks and other financial institutions. The sustainability of Credit Unions has been threatened by the incidence of loan defaults or non-performing loans. The diagnostics of the causes of loan defaults in Credit Unions become paramount toward sound credit risk management practices. The study relied on primary data. Purposive sampling technique was applied to select 244 Credit Union members. Questionnaires were used for data collection and logistic regression model was adopted. The study utilized Statistical Product and Service Solution (SPSS v. 20) and Stata (v.14) as statistical tools for data analysis. The results reveal that education, loan diversion, monitoring, marital status and income are significant factors that influence loan default. Thus, credit education should be intensified and that effective loan monitoring should be vigorously pursued. Additionally, loan appraisal systems should be robust with the application and development of credit scoring systems that will factor in key variables of loan default.
\end{abstract}

\section{Keywords}

Credit Unions, Loan Defaults, Non-Performing Loans, Factors of Loan Default

\section{Introduction}

Credit Unions provide opportunity for its members to obtain loan facilities at 
moderate interest rate and better terms and conditions such as flexible repayment terms than those offered by the banks and other financial institutions. Unfortunately, the repayment of loans granted by some Credit Unions becomes delinquent and ultimately results in bad debts which impact adversely on their overall financial performance. Loan delinquencies or defaults are constant source of misery for Credit Unions due to their adverse effects on operations in terms of profitability, liquidity, lending capacity, debt-servicing capacity as well as the ability to raise extra capital.

Ahmed [1] noted major factors affecting loan defaults as diversion of funds on the part of the borrowers, improper appraisal by credit officers, willful negligence and lack of willingness to repay loan. Balogun and Alimi [2] recognized delays in loan disbursement, loan shortages, small farm size, high interest rate, poor supervision and age of farmers as the causal factors of loan defaults. Moral hazard, large transactions cost incurred by borrowers when applying for loan, monopoly power on credit markets often exercised by informal lenders, and interest rate ceiling usually imposed by the government also come to the fore in accounting for the causes of loan defaults [3].

Loan default is a major concern to players in the Credit Union fraternity because of declining trends in profitability when loan granted becomes non-performing and the associated dire consequences on solvency. An investigation into the determinants of loan defaults therefore becomes imperative in the forward match of mapping out strategies toward the sustainability of Credit Unions in Ghana.

\section{Literature Review}

Many studies have advanced wide range of factors as determinants of loan default. They border on practices by players in financial institutions, borrower specific variables and loan delivery system as well as macro-economic factors. Socio-demographical factors have also been mentioned as causes of loan delinquencies and non-performing loans.

According to Berger and De Young [4], managers in most financial institutions are faced with the problem of non-performing loans because they do not practice adequate loan underwriting, monitoring and control. The World Bank policy research paper on non-performing loans in sub-Sahara Africa revealed that non-performing loans are caused by adverse economic shocks coupled with high cost of capital and high interest margin [5]. Goldstein and Turner [6] reported that accumulation of non-performing loans is generally due to economic downturn and volatility, term of trade deterioration, high interest rate, excessive reliance on overly high-priced interbank borrowing, insider borrowing and moral hazard. Again, poor handing over from one loan officer to another, late disbursement of loan, delayed loan process, business or crop failure and sudden change in the market have been reported as some of the factors that drive loan default or non-performing loans. For instance, an unexpected change in the market such as increase in prices of items could affect loan market; how much 
people can take as loans and subsequently how much they can pay as installment.

Ahmad [1] also reported lack of willingness to pay loan, diversion of funds, willful negligence and improper appraisal by credit officers as some of the factors that cause loan default. Balogun and Alimi [2] identified loan shortages, delays in loan delivery, small farm size, high interest rate, age of farmers and poor supervision as determinants of loan default. In addition, poor business practice and management such as record keeping, and assessing business performance over time also result in loan default. Many borrowers do not have the technical know-how to undertake their investment activities properly and as a result tend to generate low income which affects loan repayment and finally leading to loan default.

The study by Munene and Guyo [7] in Kenya showed that one of the causes of loan defaults is characteristics of the business. It was revealed that high cases of loan default were common in the manufacturing sector (67.9 percent) and was followed by the service industry (64.0 percent); agricultural sector (58.3 percent) and the trade sector recorded the least cases of loan default (34.9 percent). This least value recorded by the trade sector could be attributed to the fact that the sector deals in fast moving products on high demand which could translate into good business performance and increased revenue and hence loan could be repaid on time.

Felsovalyi and Hurt [8] found that corporate loan default increase as gross domestic product (real) decline. The authors further reported that borrowers' repayment ability is directly affected by exchange rate depreciation and hence loans demanded tend to be delinquent. Nishimura et al. [9] also reported that one of the underlying causes of Japan's prolonged economic stagnation is as a result of high non-performing or bad loans. They further explained that some of the loans disbursed to companies by financial institutions during the bubble era became non-performing when the bubble busted. This delayed structural reforms and affected the performance and proper functioning of the financial institutions. The authors finally asserted that most of the defaults were as a result of poor management procedures, loan diversion and unwillingness to repay loan.

Tuidui and Tuidui [10] averred that the higher the income of borrowers, the lower the default rate and that loan size increases with loan default. The findings are consistent to Roslan and Karim [11]; Zohair [12]; and Duly [13]. Pasha and Negege [14] on their part attributed timely disbursement of loan, loan usage on the intended purpose and time given to borrower as contributory factors of loan default. They said that timely disbursement of loan increases significantly the loan repayment performance and that there is a negative relationship between repayment and period of repayment. Wongnaa and Awunyo-Vitor [15]; explained that the longer the period of repayment, the lower the rate of default and that high repayment leads institutions to lower their interest rate and cost of 
processing loan. Roslan and Karim [11] asserted that loan tenure is negative and significant with loan repayment implying that shorter repayment period leads to higher loan repayment.

Interest rate featured prominently in works by Magali [16] and Ayogyam, Goddana, Mohammed and Boateng [17]. Whilst Magali [16] revealed that interest rate affect credit risk and profitability; Ayogyam, Goddana, Mohammed and Boateng [17] said that interest rate affect repayment of agricultural loans. Eze and Ibekwe [18]; Nawai and Shariff [19]; and Roslan and Karim [11] cited socio-demographical variables like age, gender and educational level as causes of loan default.

It can be inferred from the above review that age, sex, marital status, educational level, household size, income, diversion and monitoring are some of the determinants of loan default. These factors have positive and/or negative relationship with loan default.

The age variable is expected to have a positive relationship with loan default. That is because as one grows the ability to work reduces and therefore he/she cannot undertake much productive investment compared to younger counterparts. As a result, his/her ability to engage in diverse investment in order to earn more income also reduces and this may adversely affect their repayment capabilities hence the more likelihood of defaulting in loan repayment [2] [11] [19]. Eze and Ibekwe [18] said that age is positively significant to loan default and that younger people have better loan repayment performance.

The relationship between sex (being male) and loan default is expected to be positive. This is because, males often have more responsibilities as heads of family and as a result may use loan taken for productive investment for other purposes such as consumption, fees payment and other utility bills. This will result in difficulty in loan repayment because no income might be generated and hence the likelihood of not paying the loan on time as scheduled [18]. Roslan and Karim [11] and Wongnaa and Awunyo-Vitor [15] posited that females have good loan repayment history than their male counterparts. They advanced the propensity of economic empowerment of females emanating from credit extension and behavioral characteristics of hard work and culture of discipline as the likely reasons of satisfactory loan recoveries from females. However, Chong, Morni and Suhaimi [20]; and Nawai and Shariff [19] hold the view that either male or female borrower does not have any impact on loan repayment performance.

There is a negative relationship between being married and loan default. That is, married couples are more likely to receive support from their partners and as such loan received could be repaid on time. This may be the case in the sense that when loans are received and repayment is due the installment can be paid without necessarily affecting the fulfillment of other family needs because the partner could supplement in the provision of these needs. Therefore married respondents are less likely to default in loan repayment compared to counterparts who are either single, separated or widowed who might not have any sup- 
port from anywhere [10] [11] [12] and [13].

Education variable is expected to correlate positively with loan default. That is, individuals with lower level of education are more likely to default in loan repayment compared to counterparts who have higher levels. This is because individuals with lower level of education are likely to lack managerial skills to guide their businesses and therefore loan received might not yield enough income to enhance loan repayment on time. On the other hand, individuals with higher level of education may possess some managerial skills which can help them manage their businesses and hence more income to repay the loan received on time all things being equal [2] [11] [18], and [19].

The household size is expected to correlate positively with loan default. That is, as the number of dependents increases the responsibility also increases. As a result the income that is supposed to be used for loan repayment would be used for the provision of social and economic needs and hence the probability of not repaying loan on time (defaulting) increases all things being equal [2] [10] [11] [12] and [13].

The income variable is expected to have negative relationship with loan default. That is, individuals who earn relatively high income are expected to repay their loan on time and therefore not defaulting in loan repayment. This is so because, the substantial income earned facilitates loan repayment compared to counterparts who earn relatively low income who might find it difficult to repay their loan which may be attributed to the fact that the income is not even sufficient for the provision of social and economic need [2] [10] [11] [12] and [13].

Loan diversion is expected to have positive relationship with loan default. That is, all things being equal, if a person diverts loan received for productive investment to undertake unproductive investment, no income will be generated and this is likely to make loan repayment difficult [1] [6] [10] [11] [12] and [13].

It is expected that monitoring will have negative relationship with loan default. That is, borrowers are likely to use the loan for the intended purpose if they know Loan Officers will be monitoring their progress. As the loans are used for the intended purpose and are well managed more income will be generated and loan will be repaid on time all things being equal. On the other hand, if the borrowers are not monitored to ensure they are making progress with their business, loans received are likely to be misused and this will result in loan default [4]. This is confirmed by Wongnaa and Awunyo-Vitor [15]; Nawai and Shariff [19]; and Deininger and Liu [21] who held the view that loan repayment rate is higher in Micro Finance Institutions which pay frequent visits to the borrowers premises in a month.

\section{Methodology}

\subsection{Data and Sampling}

The study adopted purposive sampling techniques in selecting respondents. Out 
of 34 Credit Unions in the Kumasi Metropolis, 3 Credit Unions namely St. Peter's, St. Paul's and St. Martin de Pores were selected for the study. These Credit Unions were selected because they have existed for quite a longer time and have more branches compared to other Credit Unions in the Metropolis. The targeted groups for the study were therefore on Credit Unions in the Kumasi Metropolis and the members or loan customers of the Unions. The sample size for the study was 300 members who have ever received loans from the three selected Credit Unions. The distribution and sampling of the respondents are summarized in Table 1.

The study relied mainly on primary data and therefore questionnaires were designed for the data elicitation from customers who have received loans. In obtaining the data from the respondents, two approaches were adopted; self-administered and face-to-face interview. These approaches were used in order to ensure that those who can read and write and those who cannot read and write are captured in the study to avoid any biasedness.

The study used Statistical Product and Service Solution (SPSS v. 20) and Stata (v.14) as statistical tools for data analysis. These tools were used for data coding, management, cleaning and representation of the data obtained. Descriptive statistics was also conducted with the use of frequency distribution tables. These helped the researchers to effectively describe the data that was elicited from the respondents.

In order to appropriately examine the factors that influence loan default, the study employed binary logistic estimation technique and probit regression was used for robustness check of the results from the logit estimations. This is so because, the dependent variable in the study; loan default has a binary outcome response which is either "yes" or "no". That is, the respondents were asked whether they were able to repay their loan on the stipulated time in the contract. The implication is that, any respondent who was not able to repay the loan within the stipulated time is assumed to have defaulted in loan repayment and a value of 1 assigned. On the other hand members who were able to repay their loan within the specified time were assumed not to have defaulted and the value 0 assign to them. The logistic regression was chosen instead of any other estimation technique due to the dichotomous nature of the dependent variable [22] and [23].

Table 1. Distribution of sample selection.

\begin{tabular}{cc}
\hline CREDIT UNION & NUMBER LOAN CUSTOMERS/MEMBERS \\
\hline St. Peter's & 100 \\
St. Paul's & 100 \\
St. Martin de Pores & 100 \\
TOTAL & 300
\end{tabular}




\subsection{Model Specification}

The study applied a binary logistic regression due to the dichotomous nature of the dependent variable [22] and [23]. The logistic regression is therefore specified as follows:

Probability of individual defaulting in loan repayment: $p_{i}=P(D E F=1)$.

Probability of individual not defaulting in loan repayment:

$1-p_{i}=P(D E F=0)$

$$
\begin{gathered}
P(D E F=1)=p_{i}=\frac{1}{1+\mathrm{e}^{\beta_{i} x_{i}}} \\
P(D E F=0)=1-p_{i}=\frac{\mathrm{e}^{\beta_{i} x_{i}}}{1+\mathrm{e}^{\beta_{i} x_{i}}}
\end{gathered}
$$

where Equations (1) and (2) are the expressions for the probability of an individual defaulting and not defaulting in loan repayment respectively.

Introducing the odd ratio concept gives Equation (3).

$$
\text { odd }_{i}=\frac{p_{i}}{1-p_{i}}
$$

Substituting Equations (1) and (2) into Equation (3) and taking natural logarithm gives the logistic regression model specified in Equation (4).

$$
\ln \left[\frac{P(D E F=1)}{P(D E F=0)}\right]=\beta_{i} x_{i}
$$

where $\beta_{i}$ is the coefficient to be estimated and $x_{i}$ are the independent variables.

The functional form of the logistic regression for the study is given by Equation (5)

$$
\begin{aligned}
& \ln \left[\frac{P(D E F=1)}{P(D E F=0)}\right]=y \\
& =f(A G E, S E X, M A S T, E D U C, H H S, M I N C, D I V, M O N I T)
\end{aligned}
$$

where $A G E, S E X, M A S T, E D U C, H H S, M I N C, D I V$ and MONIT represent age, sex, marital status, educational level, household size, monthly income, diversion of loan and monitoring by Loan Officers respectively.

The estimable form of Equation (5) is specified in Equation (6)

$$
\begin{aligned}
y= & \beta_{0}+\beta_{1} \ln A G E+\beta_{2} S E X+\beta_{3} M A S T+\beta_{4} E D U C \\
& +\beta_{5} H H S+\beta_{6} M I N C+\beta_{7} D I V+\beta_{8} M O N I T+\mu
\end{aligned}
$$

where $y=\ln \left[\frac{P(D E F=1)}{P(D E F=0)}\right]=$ is the dependent variable, $\beta_{s}(i=1,2, \cdots, 8)$ are the coefficients of the respective independent variables and $\mu$ is the error term. The natural logarithm of age variable was used due to the larger size of the values compared to the other independent variables [22] and [23]. This is done to eliminate any possible outliers that might affect the efficiency of the result.

The interpretation of the coefficients, $\beta_{i}$ s which is the change in the probabili- 
ty of a Credit Union member defaulting as a result of a change in any of the explanatory variables, $X_{i} \mathrm{~S}$ is not straight forward. As a result, the marginal effects after the logistic regression which indicate the change in the dependent variable as a result of a change in the independent variables were estimated.

\subsection{Variables}

The dependent variable used for the study was Loan Default. The independent or explanatory variables were Age, Sex, Marital Status, Educational Level, Household Size, Monthly Income, Diversion and Monitoring. Table 2 describes the dependent and independent variables. The expected outcome of the relationship between independent variables and dependent variable is also indicated in Table 2.

\section{Results and Discussion}

Out of 300 questionnaires distributed to loan customers, 244 responses were correctly filled and finally used for the analysis giving a response rate of approximately 81 percent. Table 3 shows the Demographic Characteristics of Loan Customers or Members.

From Table 3, the results revealed that out of the 244 respondents interviewed, 123 of them representing 50.4 percent are males whiles 121 respondents representing 49.6 percent are females. By implication, majority of the Loan customers or members are males. With regard to marital status, the results showed that 38 and 163 respondents representing 15.6 and 66.8 percent respectively are single (never married) and Married. Again, the results revealed that 28 and 15 respondents are separated and widowed and these represent 11.5 and 6.1 percent respectively. This implies that majority of the respondents (163) interviewed are married. Concerning the education level of respondents, it was revealed that individuals who have attained no level of formal education are 14 representing 5.7 percent. Respondents who have attained Primary/Junior High School and Secondary Education are 28 and 76 and these represent 11.5 percent and 31.1 percent respectively. Respondents who have attained Tertiary Education (first degree) are 123 (50.4 percent) and others which include masters are 3 (1.2 percent). It can be inferred that majority of the respondents have attained tertiary education and this is followed by secondary education.

The results as indicated in Table 3 further showed that 240 of the respondents are employed whereas just 4 are unemployed and these represent 98.4 percent and 1.6 percent respectively. This suggests that most of the members of the Credit Unions are persons who are employed and this could be so to enable or facilitate loan repayment. On occupation, the results in Table 3 revealed that respondents who are farmers and traders are 16 and 94 and they represent 6.6 percent and 38.5 percent respectively. It was also revealed that 32 and 98 respondents are teachers and in the "others" category which include Doctors, Bankers, Teachers and Geomantic Engineers and these also represent 13.1 and 40.2 percent accordingly. As regards income per month, it was revealed that 3 respon- 
dents (1.2 percent) earn income up to GHS200.00. Respondents who earn income ranging from GHS201.00 to GHS400.00 and GHS401.00 to GHS600.00 were 30 and 39 which represented 12.3 and 16.0 percent in that order. Respondents who earn income of GHS601.00 to GHS800.00 and GHS801.00 to GHS1000.00 are 35 and 61 representing 14.3 and 25.0 percent accordingly. The results further showed that 76 respondents (31.1 percent) earn income above GHS 1000.00. It can therefore be inferred from these statistics that majority of the respondents (241) earn income above GHS200.00 per month. With regard to age and household size the results revealed approximately 38 years and 3 as mean values respectively. The minimum and maximum values for age are 20 years and 72 years respectively whereas those for household size are 1 and 7 in that order.

Equation (6) that is

$$
\begin{aligned}
y= & \beta_{0}+\beta_{1} \ln A G E+\beta_{2} S E X+\beta_{3} M A S T+\beta_{4} E D U C \\
& +\beta_{5} H H S+\beta_{6} M I N C+\beta_{7} D I V+\beta_{8} M O N I T+\mu
\end{aligned}
$$

was estimated to investigate the determinants of loan default. The results are presented in Table 4. The associated Logit and Probit results are shown in Appen$\operatorname{dix} 1$.

\begin{tabular}{|c|c|}
\hline Variables & Description \\
\hline $\begin{array}{l}\text { Dependent } \\
\text { [Loan default } \\
\quad(\mathrm{DEF})]\end{array}$ & $\begin{array}{l}\text { Loan default which is the dependent variable is a probability of a Credit Union } \\
\text { member or loan customer not repaying loan on time (defaulting) and repaying } \\
\text { loan on time (not defaulting). It is a dichotomous dummy variable and took the } \\
\text { value } 1 \text { if a member has ever defaulted in loan repayment and } 0 \text { if a member has } \\
\text { never defaulted in loan repayment. To capture this variable, a member who has } \\
\text { received loan was asked whether the loan was repaid on time and the responses } \\
\text { were two; either "yes" or "no". }\end{array}$ \\
\hline $\begin{array}{l}\text { Independent } \\
\text { [Age] }\end{array}$ & $\begin{array}{l}\text { The age variable represents the actual age of the respondent. The age } \\
\text { variable in the study is measured in continuous terms as the actual age (in years) } \\
\text { of the Credit Union members or loan customers interviewed. The age variable is } \\
\text { expected to have a positive relationship with loan default. }\end{array}$ \\
\hline $\begin{array}{l}\text { Independent } \\
\text { [Sex] }\end{array}$ & $\begin{array}{l}\text { Sex is the gender (male or female) of the respondents and is measured a binary } \\
\text { dummy variable. It takes the value } 1 \text { if a respondent is a male and } 0 \text { if female. The } \\
\text { relationship between sex (being male) and loan default is expected to be positive. }\end{array}$ \\
\hline $\begin{array}{c}\text { Independent } \\
\text { [Marital Status] }\end{array}$ & $\begin{array}{l}\text { Marital status variable categorizes the respondents into their respective marital } \\
\text { positions. The marital status variables has four categories and were assigned the } \\
\text { values } 1,2,3 \text { and } 4 \text { for being single, married, separated and widowed. However, } \\
\text { due to insufficient number in some of the categories which could affect the result, } \\
\text { the variable was converted to a binary dummy variable; married and other } \\
\text { category which comprises single (never married), separated and widowed. The } \\
\text { Married category was assigned the value } 1 \text { and the "other" category was assigned } \\
\text { the value } 0 \text {. The study expects a negative relationship between being married and } \\
\text { loan default. }\end{array}$ \\
\hline $\begin{array}{l}\text { Independent } \\
\text { [Educational } \\
\text { Level] }\end{array}$ & $\begin{array}{l}\text { Education variable represent the formal education received by the respondents. } \\
\text { The variable has five categories and is measured a dummy; none, primary/JHS, } \\
\text { secondary, tertiary and other which comprises higher degree. Education variable } \\
\text { is expected to correlate positively with loan default. }\end{array}$ \\
\hline
\end{tabular}

Table 2. Variables description. 


\section{Continued}

\begin{tabular}{|c|c|}
\hline $\begin{array}{l}\text { Independent } \\
\text { [Household Size] }\end{array}$ & $\begin{array}{l}\text { The household size variable represents the number of people who depend on the } \\
\text { respondent for a living. This is chosen over number of children because } \\
\text { individuals who do not have children but have other dependent are taken care of. } \\
\text { The variable is measured in continuous term and is expected to correlate } \\
\text { positively with loan default. }\end{array}$ \\
\hline $\begin{array}{l}\text { Independent } \\
\text { [Monthly } \\
\text { Income] }\end{array}$ & $\begin{array}{l}\text { The income variable represents the monthly income in Ghana cedis earned by the } \\
\text { respondents. The variable is categorized into 6; Less than or equal to GHS200.00, } \\
\text { GHS201.00-GHS400.00, GHS401.00-GHS600.00, GHS601.00-GHS800.00, } \\
\text { GHS801.00-GHS1000.00 and above GHS1000.00 and were assigned the values 1, } \\
2,3,4,5 \text { and } 6 \text { respectively. This study expects the income variable to have } \\
\text { negative relationship with loan default. }\end{array}$ \\
\hline $\begin{array}{l}\text { Independent } \\
\text { [Diversion] }\end{array}$ & $\begin{array}{l}\text { The diversion variable represents a situation whereby a member use the loan } \\
\text { received for different purpose other than the intended purpose for which the loan } \\
\text { was received. In this study it is measured as a binary } \\
\text { dummy and took the value } 1 \text { if a member uses the loan for different } \\
\text { purpose and } 0 \text { if the loan was used for the intended purpose. Loan } \\
\text { diversion is expected to have positive relationship with loan default. }\end{array}$ \\
\hline $\begin{array}{l}\text { Independent } \\
\text { [Monitoring] }\end{array}$ & $\begin{array}{l}\text { This refers to monitoring activities by the Loan Officers after a loan has been } \\
\text { disbursed. Monitoring variable is measured as a binary dummy in this study and } \\
\text { took the values } 1 \text { and } 0 \text { if borrowers were monitored and not monitored } \\
\text { respectively. It is expected that monitoring will have negative relationship with } \\
\text { loan default. }\end{array}$ \\
\hline
\end{tabular}

Source: Authors' Construct.

Table 3. Demographic characteristics of loan customers/members.

\begin{tabular}{|c|c|c|c|}
\hline \multicolumn{2}{|c|}{ DEMOGRPHICS } & \multirow{2}{*}{$\begin{array}{c}\text { FREQUENCY } \\
123\end{array}$} & \multirow{2}{*}{$\begin{array}{c}\text { PERCENTAGE } \\
50.4\end{array}$} \\
\hline SEX & Male & & \\
\hline & Female & 121 & 49.6 \\
\hline \multirow[t]{4}{*}{ MARITAL STATUS } & Single & 38 & 15.6 \\
\hline & Married & 163 & 66.8 \\
\hline & Separated & 28 & 11.5 \\
\hline & Widowed & 15 & 6.1 \\
\hline \multirow[t]{5}{*}{ EDUCATION } & No Formal Education & 14 & 5.7 \\
\hline & Primary/JHS & 28 & 11.5 \\
\hline & Secondary & 76 & 31.1 \\
\hline & Tertiary (Degree) & 123 & 50.4 \\
\hline & Other (Above Degree) & 3 & 1.2 \\
\hline \multirow[t]{6}{*}{ EMPLIOYMENT STATUS } & Employed & 240 & 98.4 \\
\hline & Unemployed & 4 & 1.6 \\
\hline & Farming & 16 & 6.6 \\
\hline & Trading & 94 & 38.5 \\
\hline & Teaching & 32 & 13.1 \\
\hline & Other & 98 & 40.2 \\
\hline \multirow[t]{2}{*}{ INCOME LEVEL } & Up to GHS200.00 & 3 & 1.3 \\
\hline & GHS201-GHS400.00 & 30 & 12.3 \\
\hline
\end{tabular}




\section{Continued}

\begin{tabular}{ccccc}
\hline & & GHS401-GHS600.00 & 39 & 16 \\
& & GHS601-GHS800.00 & 35 & 14.3 \\
& & GHS801-GHS1000.00 & 61 & 25 \\
& & Above GHS1000.00 & 76 & 31.1 \\
& Minimum & Maximum & Mean & \multicolumn{2}{c}{ Standard Deviation } \\
Age (Years) & 20 & 72 & 37.94 & 10.69 \\
Household Size & 1 & 7 & 3.08 & \multicolumn{2}{c}{1.38} \\
\hline
\end{tabular}

Source: Authors' Survey Data, 2017.

Table 4. Estimated logistic results.

\begin{tabular}{|c|c|c|c|c|}
\hline Variable & Coefficient & $\begin{array}{c}\text { Robust Std. } \\
\text { Error }\end{array}$ & $\begin{array}{c}\text { Marginal } \\
\text { Effect }\end{array}$ & Prob. value \\
\hline AGE & 0.4467 & 0.3145 & 0.1113 & 0.156 \\
\hline \multicolumn{5}{|l|}{ SEX (Female) } \\
\hline Male & 0.2776 & 0.1684 & 0.0691 & 0.099 \\
\hline \multicolumn{5}{|l|}{ MAST (Other) } \\
\hline Married & -0.3717 & 0.1841 & 0.0926 & 0.044 \\
\hline \multicolumn{5}{|l|}{ EDUCATION } \\
\hline None & 1.4745 & 0.4784 & 0.3311 & 0.002 \\
\hline Primary/JHS & 0.0862 & 0.2934 & 0.0215 & 0.769 \\
\hline Secondary & 0.3881 & 0.2114 & 0.0967 & 0.066 \\
\hline HHS & -1.3203 & 0.6965 & -0.0329 & 0.058 \\
\hline \multicolumn{5}{|l|}{ MINC (GHS200 and below) } \\
\hline GHS201.00-GHS400.00 & -15.3125 & 0.5455 & -0.8552 & 0.000 \\
\hline GHS401.00-GHS600.00 & -15.2150 & 0.5215 & -0.9154 & 0.000 \\
\hline GHS601.00-GHS800.00 & -14.9825 & 0.5212 & -0.8871 & 0.000 \\
\hline GHS801.00-GHS1000.00 & -14.5709 & 0.5162 & -0.9713 & 0.000 \\
\hline GHS1001.00 and above & -15.0539 & 0.5230 & -0.9887 & 0.000 \\
\hline \multicolumn{5}{|l|}{ DIV (No) } \\
\hline Yes & 1.1937 & 0.1854 & 0.2895 & 0.000 \\
\hline \multicolumn{5}{|l|}{ MONIT (No) } \\
\hline Yes & 0.3767 & 0.1874 & 0.0932 & 0.044 \\
\hline Constant & 12.7101 & 1.0912 & - & 0.000 \\
\hline \multicolumn{5}{|c|}{ Number of observation $=244$ Prob $>$ Chi-square $=0.0000$} \\
\hline
\end{tabular}

Source: Author's estimations using field survey data, 2017. 
Education is revealed in Table 4 to have positive relationship with loan default. That is having no formal education, Primary/JHS and Secondary education increases the probability of defaulting in loan repayment compared to having tertiary education or even higher. The marginal effect after the logit indicated that having no formal education, Primary/JHS and Secondary education increases the likelihood of defaulting by 33.1 percentage point, 2.2 percentage point and 9.7 percentage point respectively. The relationship between no formal education and loan default is significant at 1 percent significance level but that of Primary/JHS is not significant whereas the significance is weak (10 percent) for secondary education and loan default. This could be attributed to the fact that individuals who have no formal education or lower level of education are likely to lack technical and managerial skills for the management of their businesses and hence could affect their revenue and loan repayment. On the other hand, individuals with tertiary education or even higher are likely to have the technical know-how and some managerial skills which could enhance the profit of their business and hence are more likely to repayment their loan on time.

With respect to income and loan default, the study revealed a negative relationship as indicated in Table 4. Earning income of more than GHS200.00 decreases the likelihood of defaulting in loan repayment compared to earning income of less than or equal to GHS200.00. Specifically, the marginal effect value indicates that individuals who earn income of GHS201.00-GHS400.00, GHS401.00-GHS600.00, GHS601.00-GHS800.00, and GHS801.00-GHS1000.00 and above GHS1000.00 are less likely to default in loan repayment by 85.5 percentage point, 91.5 percentage points, 88.7 percentage points, 97.1 percentage points and 98.9 percentage points accordingly and these are all significant at 1 percent significance level. This relationship is expected because, individuals who earn relatively high income are able to repay their loan received on time compared to those who earn relatively low income who may find difficulties in repaying their loan hence more possibility of defaulting in loan repayment. This is consistent to the findings of Tuidui and Tuidui [10] who posited that the higher the income, the lower the default rate.

As expected, the results as showed in Table 4 revealed that there is positive relationship between loan diversion and loan default. That is, individuals who divert loans received are more likely to default compared to counterparts who do not divert the funds received. Specifically, the result shows that diverting loans received from the intended purpose increases the likelihood of defaulting in loan repayment by 28.9 percentage point as revealed by the marginal effect value and this is significant at 1 percent significance level. By implication, individuals who receive loan for business activities or other productive investment and end up using the loan for other unproductive investment may find it difficult repaying the loan because no income will be generated to facilitate loan repayment. As a result, these individuals might not be able to repay the loan on time thereby leading to loan default all things being equal. This result is consistent with the findings by Ahmad [1] and Nishimura et al. [9] who also reported that loan de- 
fault are often as a result of loan diversion by customers.

Unexpectedly, the results as depicted in Table 4 showed that there is a positive relationship between monitoring by Loan Officers and loan default. That is, being monitored by a Loan Officer is associated with an increase in the likelihood of defaulting and is statistically significant at 5 percent significance level. The marginal effect value indicated that being monitored increases the probability of defaulting by 9.3 percentage point compared to being not monitored.

This result could be possible in the sense that the Loan Officers may be monitoring the loan customers but not as effective or regular as expected. This result is not surprising to some extent as out of the 159 customers who indicated that loan officers monitor them, 125 (approximately 79 percent) mentioned that the monitoring is done once every month with only 25 (approximately 16 percent) indicating that the monitoring is done weekly. This suggests that the monthly monitoring is not effective to enhance loan repayment which needs to be addressed to make monitoring effective. Balogun and Alimi [2] have reported similar finding that loan default are at times caused by poor supervision or monitoring by Loan Officers which is similar to the findings of the study.

However, the study did not find any significant relationship between age, sex, household size and loan default. This implies that age, sex and household size do not drive loan default among Credit Unions in the Kumasi Metropolis considering the data and sample in this study. Though insignificant the relationship is positive for age, sex and loan default and negative for household size and loan default.

\section{Conclusions and Recommendations}

The study concludes that the significant factors which drive loan defaults are marital status, education, monthly income, diversion of funds and monitoring. There was no evidence of significant relationship between age, sex, household size and loan default. Based on these findings, the following recommendations are made for the attention and implementation by players in the credit management systems of Credit Unions.

1) Credit Union members who receive loan should be encouraged to work very hard and manage their funds properly to earn substantial income to facilitate loan repayment.

2) Credit and loan officers should advise members not to divert loan received for any other purpose. Also members should also be educated on the consequences of diverting funds received for unproductive activities. These are likely to reduce the rate at which customers default in loan repayment.

3) Credit and Loan officers should intensify their monitoring activities. Officers should have robust systems to monitor loan repayments daily at the office and take immediate remedial actions on undesirable repayment patterns detected. Additionally, monitoring of loan activities outside the office or field visits could be done at least on weekly basis instead of monthly. 
4) The development and applications of credit scoring systems in loan appraisals, recommendations and approvals are long overdue in the credit risk management systems of Credit Unions. Credit scoring systems will not only factor in key determinants of loan defaults like marital status, education and monthly income but also make the loan appraisal systems robust and thereby minimize the inherent risks associated with the granting of loans to Credit Union members.

\section{Conflicts of Interest}

The authors declare no conflicts of interest regarding the publication of this paper.

\section{References}

[1] Ahmad, S.A. (1997) Natural Hazards and Hazard Management in the Greater Caribbean and Latin America. The University Printers Publication, University of West Indies, Kingston, Jamaica, No. 3.

[2] Balogun, E.D. and Alimi, A. (1988) Loan Delinquency among Small Farmers in Developing Countries: A Case Study of the Small-Farmer Credit Programme in Lagos State of Nigeria. CBN Economic and Financial Review, 26, 67-72.

[3] Kohansal, M.R. and Mansoori, H. (2009) Factors Affecting Loan Repayment Performance of Farmers in Khorsan-Razavi Province of Iran. Conference on International Research on Food Security, Natural Resource Management and Rural Development, University of Hamburg, 1-4.

[4] Berger, A.N. and De Young, R. (1997) Problem Loans and Cost Efficiency in Commercial Banks. Journal of Banking \& Finance, 21, 849-870. https://doi.org/10.1016/S0378-4266(97)00003-4

[5] Fofack, H.L. (2005) Nonperforming Loans in Sub-Saharan Africa: Causal Analysis and Macroeconomic Implications (English). Policy, Research Working Paper, No.WPS 3769, World Bank, Washington, DC.

[6] Goldstein, M. and Philip, T. (1996) Banking Crises in Emerging Economies: Origins and Policy Options. BIS Economic Paper No. 46, Bank for International Settlements, Basel.

[7] Munene, H.N. and Guyo, S.H. (2013) Factors Influencing Loan Repayment Default in Micro-Finance Institutions: The Experience of Imenti North District, Kenya. International Journal of Applied science \& Technology, 3, 67-72.

[8] Fersolvalyi, A. and Hurt, L. (1998) Measuring Loss on Latin American Defaulted Bank Loans: A 27-Year Study of 27 Countries. Journal of Lending and Credit Risk Management, 80, 41-46.

[9] Nishimura, K., Kazuhito I. and Yukiko O. (2001) The Disposal of Non-Performing Loans and Its Potential Influence. http://www5.cao.go.jp/keizai3/2001/0628furyousaiken-e.pdf

[10] Tundui, C. and Tundui, H. (2013) Microcredit, Micro Enterprising and Repayment Myth: The Case of Micro and Small Women Business Entrepreneurs in Tanzania. American Journal of Business and Management, 2, 20-30.

https://doi.org/10.11634/216796061302240

[11] Roslan, A.H. and Karim, M.Z.A. (2009) Determinants of Microcredit Repayment in 
Malaysia: The Case of Agrobank. Humanity \& Social Science Journal, 4, 45-52.

[12] Zohair, M. (2013) Factors Affecting Repayment of Loans by Micro-Borrowers in Tunisia: An Empirical Study. Journal of Management and Public Policy, 4, 4-16.

[13] Duy, V.Q. (2013) Is The Repayment Performance of Farmers Better Than That of Non-Farmers? A Case Study of Borrowers of Formal Bank Credit in the Mekong Delta, Vietnam. CAS Discussion Paper No. 88.

[14] Pasha, S.M.A. and Negese, T. (2014) Performance of Loan Repayment Determinants in Ethiopian Micro Finance: An Analysis. Eurasian Journal of Business and Economics, 7, 29-49.

[15] Wongnaa, C.A. and Vitor, D.A. (2013) Factors Affecting Loan Repayment Performance among Yam Farmers in the Sene District, Ghana. Agris On-Line Papers in Economics and Informatics, 5, 111-122.

[16] Magali, J.J. (2013) The Impacts of Credit Risk Management on Profitability of Rural Savings and Credits Cooperative Societies (SACCOS): The Case Study of Tanzania. Journal of management Sciences and Business Research, 2, 62-75.

[17] Ayogyam, A., Goddana, M.D., Mohammed, H. and Boateng, E. (2013) Monitoring Loan Repayment among Farmers in Techiman, Ghana: Investigating the Effect of Cooperative Farming System. Journal of Emerging Trends in Economics and Management Sciences, 5, 32-37.

[18] Eze, C.C. and Ibekwe, U.C. (2007) Determinants of Loan Repayment under Indigenous Financial System in Southeast, Nigeria. Medwell Journals, 2, 116-120.

[19] Nawai, N. and Shariff, M.N.M. (2012) Factors Affecting Repayment Performance in Microfinance Programs in Malaysia. Procedia-Social and Behavioral Sciences, 62, 806-811. https://doi.org/10.1016/j.sbspro.2012.09.136

[20] Chong, F., Morni, F. and Suhaimi, R. (2010) Demographic Factors and Repayment Performance of NBFI Customers in Kuching. 2010 International Conference on Science and Social Research (CSSR 2010), Kuala Lumpur, 5-7 December 2010, 1340-1345. https://doi.org/10.1109/CSSR.2010.5773748

[21] Deininger, K. and Liu, Y. (2009) Determinants of Repayment Performance in Indian Micro-Credit Groups. The World Bank, Washington DC. https://doi.org/10.1596/1813-9450-4885

[22] Greene, W.H. (2003) Econometrics Analysis. 5th Edition, Prentice Hall, Upper Saddle River, New Jessey.

[23] Asteriou, D. and Hall, S.G. (2011) Applied Econometrics. 2nd Edition, Palgrave Macmillan, New York. 


\section{Appendix I: Logit and Probit Results}

\section{LOGIT RESULTS}

Logistic regression Number of obs $=244$;

Wald chi2 (14) = 1164.79;

Prob $>$ chi $2=0.0000$;

Log pseudo likelihood $=-423.93157$ Pseudo $\mathrm{R} 2=0.1015$.

\begin{tabular}{|c|c|c|c|c|c|c|}
\hline \multirow{3}{*}{$\begin{array}{l}\text { DEF_YES } \\
\text { AGE }\end{array}$} & \multicolumn{6}{|l|}{ Robust } \\
\hline & \multirow{2}{*}{$\begin{array}{l}\text { Coef. } \\
0.4467175\end{array}$} & \multirow{2}{*}{$\begin{array}{l}\text { Std. Err. } \\
0.3145239\end{array}$} & \multirow{2}{*}{$\begin{array}{l}\mathrm{z} \\
1.42\end{array}$} & \multirow{2}{*}{$\begin{array}{l}\mathbf{P}>|\mathbf{z}| \\
0.156\end{array}$} & \multicolumn{2}{|c|}{ [95\% Conf. Interval] } \\
\hline & & & & & -0.1697381 & 1.063173 \\
\hline SEX_MALE & 0.2775955 & 0.1683661 & 1.65 & 0.099 & -0.0523959 & 0.607587 \\
\hline MAST_MARRIED & -0.3717063 & 0.1841267 & -2.02 & 0.044 & -0.732588 & -0.0108247 \\
\hline EDUC_NONE & 1.474625 & 0.4783822 & 3.08 & 0.002 & 0.5370135 & 2.412237 \\
\hline EDUC_PRIMARY_JHS & 0.0862184 & 0.2933938 & 0.29 & 0.769 & -0.4888228 & 0.6612596 \\
\hline EDUC_SECONDARY & 0.3881549 & 0.2114274 & 1.84 & 0.066 & -0.0262351 & 0.8025449 \\
\hline HHS & -0.1320329 & 0.0696498 & -1.90 & 0.058 & -0.2685439 & 0.0044781 \\
\hline MINC_201_400 & -15.31255 & 0.5455137 & -28.07 & 0.000 & -16.38174 & -14.24336 \\
\hline MINC_401_600 & -15.21498 & 0.5215329 & -29.17 & 0.000 & -16.23716 & -14.19279 \\
\hline MINC_601_800 & -14.98249 & 0.5211908 & -28.75 & 0.000 & -16.004 & -13.96097 \\
\hline MINC_801_1000 & -14.57087 & 0.5162406 & -28.22 & 0.000 & -15.58269 & -13.55906 \\
\hline MINC_ABOVE_1000 & -15.05392 & 0.5229786 & -28.78 & 0.000 & -16.07894 & -14.0289 \\
\hline DIV_YES & 1.193668 & 0.1854375 & 6.44 & 0.000 & 0.8302176 & 1.557119 \\
\hline MONIT_YES & 0.3766966 & 0.1873804 & 2.01 & 0.044 & 0.0094377 & 0.7439555 \\
\hline _cons & 12.71007 & 1.091254 & 11.65 & 0.000 & 10.57125 & 14.84889 \\
\hline
\end{tabular}

. $\mathrm{mfx}$

Marginal effects after logit

$\mathrm{y}=\operatorname{Pr}\left(\mathrm{DEF} \_\mathrm{YES}\right)$ (predict)

$=0.47169733$

\begin{tabular}{|c|c|c|c|c|c|c|c|}
\hline variable & $\mathrm{dy} / \mathrm{dx}$ & Std. Err. & $\mathrm{z}$ & $P>|z|$ & [95\% C.I.] & & $\mathrm{X}$ \\
\hline AGE & 0.1113215 & 0.07841 & 1.42 & 0.156 & -0.04236 & 0.265003 & 3.59642 \\
\hline SEX_MALE* & 0.0690612 & 0.04173 & 1.65 & 0.098 & -0.012728 & 0.15085 & 0.50508 \\
\hline MAST_M D ${ }^{*}$ & -0.0925951 & 0.04568 & -2.03 & 0.043 & -0.182128 & -0.003062 & 0.661829 \\
\hline EDUC_N $\sim \mathrm{E}^{*}$ & 0.3311213 & 0.0837 & 3.96 & 0.000 & 0.167077 & 0.495166 & 0.056604 \\
\hline EDUC_P $\sim S^{*}$ & 0.0215166 & 0.07329 & 0.29 & 0.769 & -0.122129 & 0.165163 & 0.11611 \\
\hline EDUC_S $\sim Y^{*}$ & 0.0966973 & 0.0524 & 1.85 & 0.065 & -0.006012 & 0.199407 & 0.310595 \\
\hline HHS & -0.0329025 & 0.01737 & -1.89 & 0.058 & -0.066938 & 0.001133 & 3.08128 \\
\hline MINC $\sim 400^{*}$ & -0.855168 & 0.01391 & -61.46 & 0.000 & -0.882438 & -0.827898 & 0.123367 \\
\hline MINC $\sim 600^{*}$ & -0.9154427 & 0.00925 & -98.95 & 0.000 & -0.933576 & -0.897309 & 0.164006 \\
\hline
\end{tabular}


Continued

\begin{tabular}{cccccccc}
\hline MINC $\sim 800^{*}$ & -0.8870715 & 0.01166 & -76.09 & 0.000 & -0.909922 & -0.864221 & 0.145138 \\
MINC_8 0* & -0.9713498 & 0.00429 & -226.47 & 0.000 & -0.979756 & -0.962943 & 0.249637 \\
MINC_A $~ 0$ & -0.988712 & 0.00198 & -499.75 & 0.000 & -0.99259 & -0.984834 & 0.30479 \\
DIV_YES* & 0.2894939 & 0.04215 & 6.87 & 0.000 & 0.206876 & 0.372111 & 0.342525 \\
MONIT_ S* $^{*}$ & 0.0932324 & 0.04584 & 2.03 & 0.042 & 0.003382 & 0.183082 & 0.648766 \\
\hline
\end{tabular}

$\left.{ }^{*}\right) \mathrm{dy} / \mathrm{dx}$ is for discrete change of dummy variable from 0 to 1 .

\section{PROBIT RESULTS}

Probit regression Number of obs $=244$;

Wald chi2 $(14)=1524.07$;

Prob > chi2 $=0.0000$;

Log pseudolikelihood $=-424.16438$ Pseudo R2 $=0.1010$.

\begin{tabular}{|c|c|c|c|c|c|c|}
\hline \multirow{3}{*}{$\frac{\text { DEF_YES }}{\text { lnage }}$} & \multicolumn{6}{|l|}{ Robust } \\
\hline & \multirow{2}{*}{$\begin{array}{l}\text { Coef. } \\
0.2756151\end{array}$} & \multirow{2}{*}{$\begin{array}{l}\text { Std. Err. } \\
0.1912444\end{array}$} & \multirow{2}{*}{$\begin{array}{l}\mathrm{z} \\
1.44\end{array}$} & \multirow{2}{*}{$\frac{P>|z|}{0.150}$} & \multicolumn{2}{|c|}{ [95\% Conf. Interval] } \\
\hline & & & & & -0.099217 & 0.6504471 \\
\hline SEX_MALE & 0.1654421 & 0.1019268 & 1.62 & 0.105 & -0.0343308 & 0.3652149 \\
\hline MAST_MARRIED & -0.214963 & 0.1110802 & -1.94 & 0.053 & -0.4326763 & 0.0027502 \\
\hline EDUC_NONE & 0.8686811 & 0.2824145 & 3.08 & 0.002 & 0.3151588 & 1.422203 \\
\hline EDUC_PRIMARY_JHS & 0.0457249 & 0.1799459 & 0.25 & 0.799 & -0.3069626 & 0.3984124 \\
\hline EDUC_SECONDARY & 0.2349704 & 0.1293101 & 1.82 & 0.069 & -0.0184728 & 0.4884135 \\
\hline HHS & -0.0844469 & 0.041944 & -2.01 & 0.044 & -0.1666557 & -0.0022381 \\
\hline MINC_201_400 & -5.671145 & 0.2727414 & -20.79 & 0.000 & -6.205709 & -5.136582 \\
\hline MINC_401_600 & -5.613304 & 0.244171 & -22.99 & 0.000 & -6.091871 & -5.134738 \\
\hline MINC_601_800 & -5.472771 & 0.2436211 & -22.46 & 0.000 & -5.950259 & -4.995282 \\
\hline MINC_801_1000 & -5.228446 & 0.2397905 & -21.80 & 0.000 & -5.698427 & -4.758466 \\
\hline MINC_ABOVE_1000 & -5.524103 & 0.2417911 & -22.85 & 0.000 & -5.998005 & -5.050201 \\
\hline DIV_YES & 0.7278408 & 0.1111007 & 6.55 & 0.000 & 0.5100874 & 0.9455941 \\
\hline MONIT_YES & 0.2177106 & 0.1114723 & 1.95 & 0.051 & -0.000771 & 0.4361922 \\
\hline _cons & 4.093076 & 0.604622 & 6.77 & 0.000 & 2.908038 & 5.278113 \\
\hline
\end{tabular}

. $\mathrm{mfx}$

Marginal effects after probit

$\mathrm{y}=\operatorname{Pr}\left(\mathrm{DEF} \_\mathrm{YES}\right)$ (predict)

$=0.45221805$

\begin{tabular}{clllllll}
\hline variable & $\mathrm{dy} / \mathrm{dx}$ & Std. Err. & $\mathrm{z}$ & $\mathrm{P}>|\mathrm{z}|$ & [95\% C.I.] & $\mathrm{X}$ \\
\hline lnage & 0.1091649 & 0.07578 & 1.44 & 0.150 & -0.039357 & 0.257687 & 3.59642 \\
SEX_MALE* $^{*}$ & 0.0654477 & 0.04021 & 1.63 & 0.104 & -0.013371 & 0.144267 & 0.50508 \\
\hline
\end{tabular}




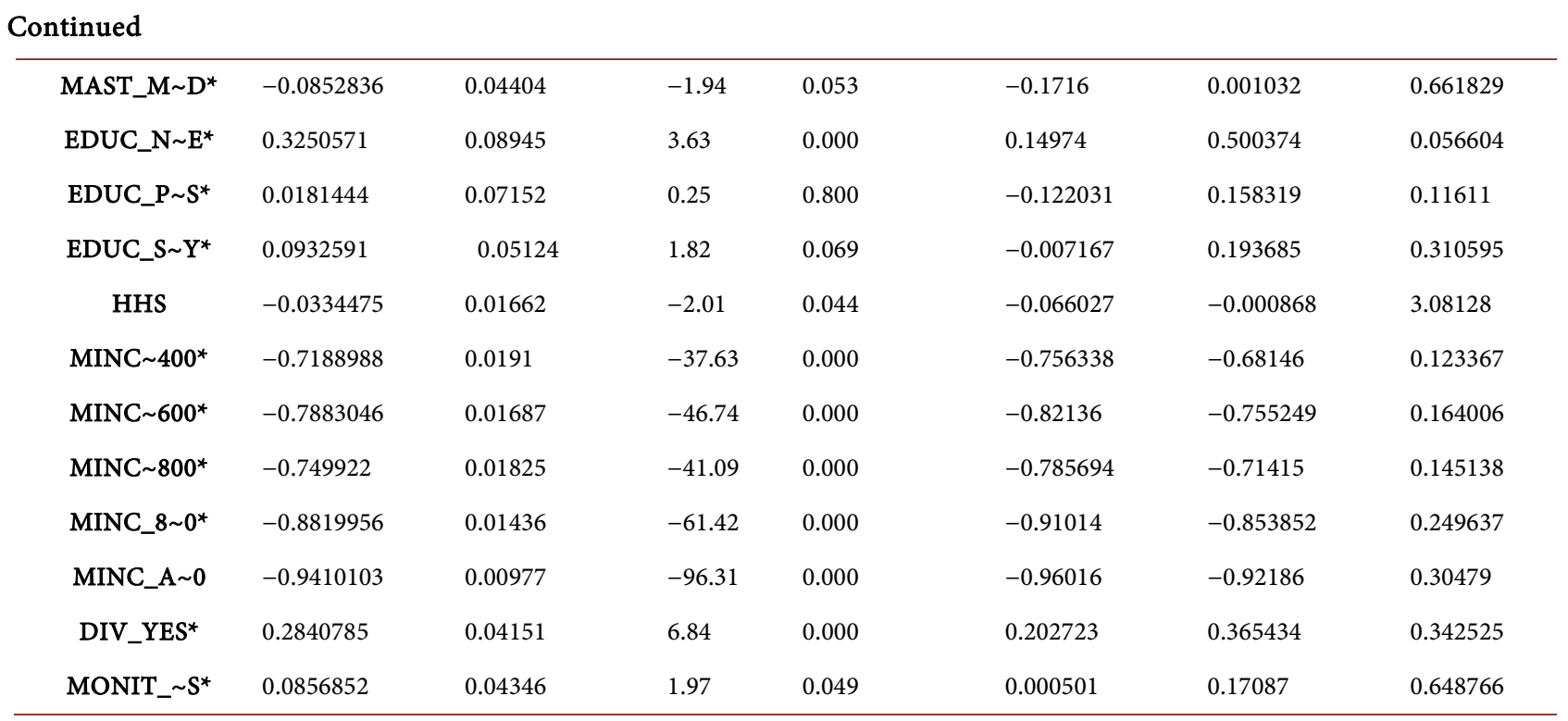

$\left.{ }^{*}\right) \mathrm{dy} / \mathrm{dx}$ is for discrete change of dummy variable from 0 to 1 . 